\title{
Tracing cross species transmission of Mycobacterium bovis at the wildlife/ livestock interface in South Africa
}

\author{
Petronillah R. Sichewo ${ }^{1,2^{*}}$, Tiny M. Hlokwe ${ }^{3}$, Eric M. C. Etter ${ }^{4,5,6}$ and Anita L. Michel ${ }^{1,7}$
}

\begin{abstract}
Background: Bovine tuberculosis (bTB) affects cattle and wildlife in South Africa with the African buffalo (Syncerus caffer) as the principal maintenance host. The presence of a wildlife maintenance host at the wildlife/livestock interface acting as spill-over host makes it much more challenging to control and eradicate bTB in cattle. Spoligotyping and mycobacterial interspersed repetitive unit-variable number of tandem repeat (MIRU-VNTR) genotyping methods were performed to investigate the genetic diversity of Mycobacterium bovis (M. bovis) isolates from cattle and wildlife, their distribution and transmission at the wildlife/livestock interface in northern Kwa-Zulu Natal (KZN), South Africa.
\end{abstract}

Results: SB0130 was identified as the dominant spoligotype pattern at this wildlife/livestock interface, while VNTR typing revealed a total of 29 VNTR profiles (strains) in the KZN province signifying high genetic variability. The detection of 5 VNTR profiles shared between cattle and buffalo suggests M. bovis transmission between species. MIRU-VNTR confirmed co-infection in one cow with three strains of M. bovis that differed at a single locus, with 2 being shared with buffalo, implying pathogen introduction from most probably unrelated wildlife sources.

Conclusion: Our findings highlight inter and intra species transmission of bTB at the wildlife/livestock interface and the need for the implementation of adequate bTB control measures to mitigate the spread of the pathogen responsible for economic losses and a public health threat.

Keywords: African buffalo, Bovine tuberculosis (bTB), Cattle, Mycobacterium bovis (M. bovis), Strains, Wildlife, Wildlife/ livestock interface

\section{Background}

Mycobacterium bovis (M. bovis) is host adapted to cattle where it causes bovine tuberculosis (bTB); but is also a multi-host pathogen that affects other domesticated animals, wildlife and humans [1]. The disease has been nearly eradicated in developed countries, but it

\footnotetext{
* Correspondence: psichewo@gmail.com

${ }^{1}$ Department of Veterinary Tropical Diseases, Bovine Brucellosis and

Tuberculosis Research Programme, Faculty of Veterinary Science, University of Pretoria, Pretoria, Republic of South Africa

${ }^{2}$ Department of Animal Sciences, Faculty of Natural Resources Management and Agriculture, Midlands State University, Gweru, Zimbabwe

Full list of author information is available at the end of the article
}

is widespread in developing countries where it is considered a risk to veterinary and public health and has a negative economic impact and threatens livelihoods [2-4].

The occurrence of wildlife maintenance hosts has complicated the control of the disease especially at the wildlife/livestock/human interface where there is overlapping of territories due to encroachment of human activities into wildlife conservation areas and potential escape of wildlife from these areas [5-8]. Cross-species transmission of bTB has been documented at the wildlife/livestock interface, with wildlife maintenance hosts such as the African buffalo (Syncerus caffer) in South

(c) The Author(s). 2020 Open Access This article is licensed under a Creative Commons Attribution 4.0 International License, which permits use, sharing, adaptation, distribution and reproduction in any medium or format, as long as you give appropriate credit to the original author(s) and the source, provide a link to the Creative Commons licence, and indicate if changes were made. The images or other third party material in this article are included in the article's Creative Commons licence, unless indicated otherwise in a credit line to the material. If material is not included in the article's Creative Commons licence and your intended use is not permitted by statutory regulation or exceeds the permitted use, you will need to obtain permission directly from the copyright holder. To view a copy of this licence, visit http://creativecommons.org/licenses/by/4.0/ The Creative Commons Public Domain Dedication waiver (http://creativecommons.org/publicdomain/zero/1.0/) applies to the data made available in this article, unless otherwise stated in a credit line to the data. 
Africa and the Kafue lechwe antelopes (Kobus leche kafuensis) in Zambia [9-11]. Several wildlife maintenance hosts have also been recognized in some developed countries as significant sources of infection and make it difficult to control as well as eradicate bTB in cattle [12-17] .

In South Africa bovine tuberculosis affects cattle and has been documented in several wildlife species for example lion, buffalo, cheetah,hyena, impala, kudu, nyala and others $[18,19]$. Intra and inter species transmission of $M$. bovis occurs through direct contact (inhalation of contaminated aerosol) or through the consumption of contaminated food or water $[5,20]$. Bovine TB is prevalent in the African buffalo in the Hluhluwe iMfolozi Park (HiP) and spill-over to a range of other wild animal species such as lion, chacma baboon, bush pig and warthog has been reported [17, 21, 22]. Molecular analysis of $M$. bovis isolates from wildlife has revealed spoligotype patterns that are being shared with communal cattle thereby suggesting cross-species transmission of bovine tuberculosis at the wildlife/livestock/human interface [18]. In addition, the absence of an effective bTB control programme in cattle, consumption of contaminated raw animal products and a high prevalence of HIV/AIDS exacerbates the risk of zoonotic TB in communities living at the wildlife/livestock/human interface [1, 23-25].

Genotyping methods are used in epidemiological studies to trace the origin of infections, understand the circulation of the pathogen in particular populations and provide information of transmission pathways [26]. The data from these studies are useful for the development of functioning bTB control and management programs especially at the wildlife/livestock/human interface [6, 21]. Spoligotyping and MIRU-VNTR are genotyping techniques that have been recently adopted for use in molecular epidemiology for the discrimination of isolates in the Mycobacterium tuberculosis complex based on the analysis of the repeated sequences in the bacterial genome [27]. These methods are reliable and rapidly provide information on the genetic structure, identification of epidemiological links and the pattern of disease occurrence [27].

Spoligotyping, uses polymerase chain reaction (PCR) and reverse-hybridization blotting to evaluate the genetic diversity of $M$. tuberculosis complex isolates using the Direct Repeat locus (DRs) and its unique spacer sequence for the differentiation of these organisms [28]. The results reveal the presence or absence of individual spacer sequences and can be compared with an international database of spoligotype (www.Mbovis.org) [29]. The MIRU-VNTR technique, characterizes mycobacterial interspersed repetitive units (MIRU) based on the variable number of tandem repeats [27]. Research groups have identified different combinations of VNTR loci for typing of $M$. bovis and variation according to geographical location has been documented hence, there is a need for a specific panel of loci in a region [30].

The study area is a communal farmland that is surrounded by public and private game reserves where bTB has been previously reported in wildlife, such as the Hluhluwe iMfolozi Park (HiP), Munyawana and Mkhuze game reserves $[22,31]$. Recently bTB was detected in traditionally farmed cattle in this wildlife/livestock interface [32]. Currently, there is inadequate information on the inter species transmission of bTB between the game reserves and neighbouring communities. Therefore, the aim of the study was to investigate the population structure of $M$. bovis strains in wildlife and cattle and assess the transmission of bTB across these species at this wildlife/livestock interface.

\section{Results Spoligotyping}

A total of $99 \mathrm{M}$. bovis isolates were obtained from culture of wildlife and cattle samples. Fifty-one (51) isolates were derived from cattle, 41 isolates from buffalo, 4 isolates from lion, 2 isolates from baboons and one from a warthog. The isolates were confirmed as $M$. bovis as they lacked spacer 3,9,16 and 39-43 in the spoligotype patterns which is a feature that is used to distinguish $M$. bovis from Mycobacterium tuberculosis (M. tuberculosis). A total of five spoligotype patterns were identified. The predominant pattern was SB0130 that lacked additional spacer 11. Out of the five spoligotype patterns, two spoligotypes were shared between cattle and wildlife (SB0130; SB0140); SB2199, SB0121 and SB0267 were found in cattle only as shown in Fig. 1. Spoligotype SB0140 was identified in isolates from baboons and warthog from Mkhuze game reserve, lions from Munyawana game park, African buffaloes from HiP and cattle from a farm near the town of Bergville. The spoligotype patterns were characterised by a lack of additional spacers and named according to the corresponding spoligopatterns found in the international standard database (www.Mbovis.org).

\section{Mycobacteria interspersed repetitive unit-variable number of tandem repeats (MIRU-VNTR)}

Using the 13 loci VNTR panel, 29 distinct genetic profiles were identified from the 5 spoligotypes. The VNTR profiles were designated (genotype)1-29 for identification purposes on the dendogram in Fig. 1. Five VNTR profiles were shared between buffalo and cattle, whilst other wildlife species did not share profiles with cattle. Ten VNTR profiles were exclusively found in buffalo while another set of 10 profiles were detected in cattle only. One VNTR profile was shared between a baboon and warthog, while 2 


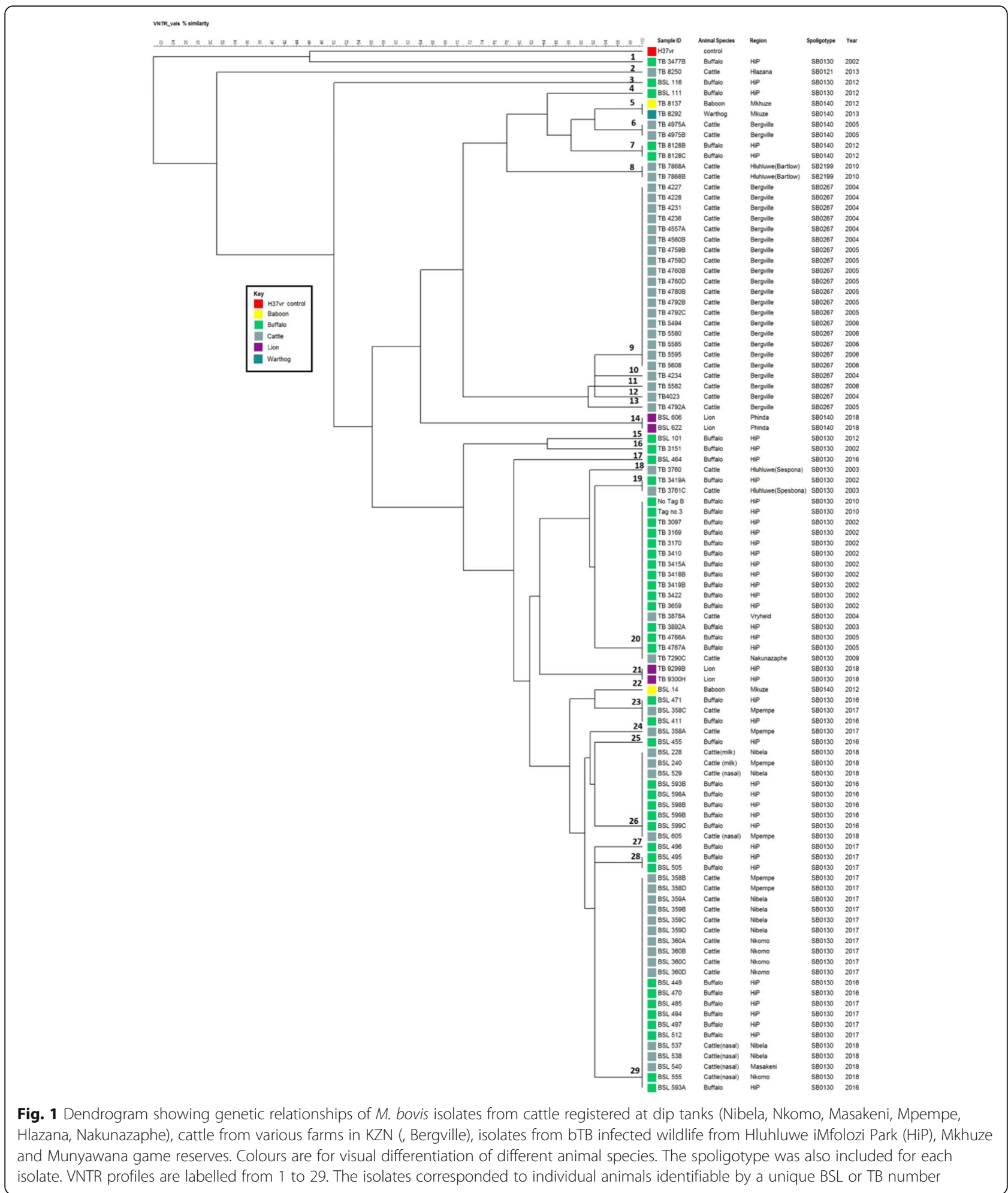

VNTR profiles and 1 VNTR profile were exclusively found in lions and a baboon, respectively.

SB0130 spoligotype pattern was differentiated into 17 genetic profiles, whereby 5 profiles were shared between cattle and buffalo, 9 being singletons in buffalo, 2 profiles in cattle only and 1 profile in lions only from HiP, as shown in Fig. 1. Co-infection with different strains was detected in tissues from one cow (BSL358) that had 3 genetic profiles that differed at one locus with two of the profiles being shared with different buffaloes (VNTR 23 
and 29) and one singleton VNTR 24. Sharing of VNTR profiles was also revealed between cattle from different dip tanks and some farms in the province. VNTR 26 was shared by $M$. bovis isolates from cattle (milk and nasal swabs samples) and tissue samples from buffaloes. VNTR 29 was shared by $M$. bovis isolates from cattle nasal swabs, tissues and buffalo tissue samples.

SB0140 was differentiated into 6 VNTR profiles that included; VNTR 6 in cattle, VNTR 7 in buffalo from HiP, VNTR 5 being shared by a baboon and warthog from Mkhuze game park, one singleton in a baboon (VNTR 22), VNTR 14 and VNTR 21 in lions from Munyawana and HiP game parks, respectively. SB0267 had 5 VNTR profiles (VNTR 9-13) from cattle isolates obtained from a single farm in Bergville as depicted in Fig. 1.

\section{Discussion}

This study investigated the genetic diversity of $M$. bovis isolates at the wildlife/livestock interface in northern Kwa-Zulu Natal province, South Africa. The results suggested inter-herd and inter-species transmission based on the spoligotype pattern and VNTR types being shared between cattle from different dip tanks or farms and buffalo.

A high genetic variability of $M$. bovis strains in South African cattle populations has previously been reported $[18,21]$ and has remained unchanged over more than two decades, as shown in this study. Genetic variability displayed in the VNTR profiles in cattle in our study area (15 VNTR profiles) either infers several local and stable sources of infection or the long-term persistence and evolution of one or more precursor strains. The spoligotypes SB0130 and SB0140 strains are linked to the European 1 (Eu1) clonal complex and where possibly introduced into the country during cattle imports from the UK during colonial times [21,33]. Thus, the numerous VNTR types might be related to the earlier introduction of bTB into this community; as it has been proposed that persistence of an infection presents more opportunities for genetic evolution [21].

The identical VNTR profiles that were detected in isolates from cattle and African buffalo over the years strongly indicate cross species transmission. High clonality revealed by the isolates indicate the active and recent transmission of $M$. bovis between animal species as previously reported [10]. Hence, the presence of clusters of wildlife and cattle isolates means that related isolates of $M$. bovis are spreading at the wildlife/livestock interface. The presence of $M$. bovis in buffalo is of significance as these represent a maintenance host that can re-infect cattle populations as documented by Musoke et al. (2015) [10]. This is supported by activities that involve wildlifeto-livestock contact at this interface as these have been identified as highly significant risk factors for $M$. bovis infection in cattle [34].

Co-infection was confirmed by the isolation of multiple strains of $M$. bovis in one cow BSL 358 (VNTR 23, 24, 29) with VNTR 23 and 29 profiles being shared with buffaloes. Multiple strain infections demonstrate repeated transmission events caused by several sources of infection or the evolution of 'old' strains within the animal populations. The former is in line with the communal production system at the wildlife/livestock interface that is characterised by intermingling of cattle and contact with wildlife at shared resources [34-37]. Hlokwe et al., (2011) reported co-infection of two or more spoligotypes in cattle from the same farm (herd) as an indicator of independent unrelated sources of infections [31]. However, in this study, the VNTR strains detected in the cow (BSL358) shared the same spoligotype and only differed at only one locus suggestive of strain evolution or mutation in the cow following a single infection. A study in Ireland reported co- infection in one badger (three spoligotypes and three VNTR strains that differed at more than one locus) as an indicator of repeated exposure of the animal to various sources of infection hence the numerous $M$. bovis strains [38].

The excretion of $M$. bovis in milk and nasal discharges detected in bTB infected cattle herds facilitates both intra and inter species transmission [25] during direct contact at shared feed or water sources or, in the case of humans, through consumption of contaminated milk. The traditional cattle farming practices that were reported by the farmers in our previous study promote contact of infected herds with uninfected herds at common watering points and pastures [34]. These results conform to the previous findings that reported SB0130 as one of the major spoligotypes that cause M. bovis infection in wildlife and cattle in South Africa [18, 21, 31]. In particular, spoligotype SB0130 was dominant in cattle as well as wildlife between 1993 and 2013 [18, 21] and still most frequently isolated in our study (from 2002 to 2018). We believe this trend is an indicator of ineffective control measures that fail to eradicate the strain from cattle, and points to a continuous risk of infection and or re-infection to wildlife and cattle.

The other factors that contribute to the maintenance of the infection are the results of unsuitable animal management practices, for example, free movement of cattle that leads to intermingling of animals with different bTB status, trade of infected animals and inadequate biosafety measures. As suggested in literature, biological, ecological and anthropological factors influence the transmission of $M$. bovis at the wildlife/livestock interface [9]. At this wildlife/livestock interface introduction of cattle into herds without bTB pre-testing for traditional purposes and the co-grazing of cattle with wildlife 
as well as sharing of water sources were recognized as risky practices for bTB transmission to cattle [34].

MIRU-VNTR revealed a high genetic variability in the 5 spoligotype patterns using the previously evaluated 13 VNTR locus for South African isolates [39], indicative of its superior discriminatory power over spoligotyping. The slowly mutating marker that is used in spoligotyping indicates the evolutionary history of isolates and is useful in the evaluation of eradication programs. Whilst the more rapidly evolving markers that are used in MIRU-VNTR are suitable for tracking transmission and determining the origins of outbreaks [40]. The use of both spoligotyping and MIRU- VNTR in combination provided a better insight into the epidemiology of bTB and evaluation of the control program, thus suitable solutions could be designed for South Africa.

As reported by Haddad et.al. (2001), a comparative study of $M$. tuberculosis strain diversity between developed and developing countries, concluded that in a high human TB prevalence situation, a dominant spoligotype will most likely exclude other types [41]. Whereas, in a low human TB prevalence situation more $M$. tuberculosis genotypes can be present. This has been established in the context of bTB in cattle with reference to numerous genotypes displayed by $M$. bovis isolates from developed countries where bTB prevalence is low due to successful national control programs [40]. In our study setting where a high bTB was found [32], the SBO130 was dominant in both cattle and wildlife, indicative of a poor efficacy of current control measures in this communal area.

\section{Conclusion}

The findings from this study highlights the significance of wildlife (African buffalo) and cattle in the persistence of $M$. bovis infection at the wildlife/livestock interface. National bTB control programs need not only to focus on cattle but also consider the role of wildlife and their transmission dynamics for complete bTB eradication. Co-operation from all relevant stake holders is necessary for the application of stringent control measures in both traditionally farmed cattle and wildlife to successfully reduce $\mathrm{bTB}$ at the wildlife/livestock interface.

\section{Methods}

\section{Study area}

The cattle samples were obtained from animals that were bTB tested during a cross-sectional study that was conducted at 4 dip tanks (Nibela, Nkomo, Mpempe, Masakeni) in Big 5 False Bay Municipality, in uMkhanyakude district, northern KwaZulu-Natal province, South Africa. Bovine TB testing of cattle was previously carried out in September 2016 and March 2017 as part of a One Health investigation into the epidemiology of
bTB at the wildlife/livestock/human interface [32]. Additional cattle samples were collected from farms and other dip tanks in the province during bTB outbreaks. Wildlife samples were collected from the surrounding game reserves that include $\mathrm{HiP}$, Munyawana and Mkhuze. The map of the study area has been previously described by (Sichewo et al., (2019) [32].

The study area is defined as a wildlife/livestock/human interface due to the communal farmland being bordered by game farms or reserves where $M$. bovis infection has been diagnosed in African buffalo and other wildlife species [42]. The farmers in this community depend on subsistence agriculture and livestock as their main source of income [43]. Uncontrolled movement of livestock into/near game reserves during the dry seasons or periods of extensive drought is a common practice in the area.

\section{Sample collection and processing Milk, nasal and tissue samples from cattle}

In June and July 2017, 30 milk samples were collected from interferon gamma positive animals that belonged to the 4 dip tanks were bTB testing was previously carried out in September 2016 and March 2017 [32]. An average of $25 \mathrm{ml}$ of milk was collected into $50 \mathrm{ml}$ centrifuge tubes from all lactating animals. A total of 99 nasal swabs were collected from the same bTB infected herds, [32] through random sampling using $50 \mathrm{~cm}$ handmade swabs that were placed into phosphate buffer as the transport medium. The milk samples were frozen, and the nasal swabs were placed at $4{ }^{\circ} \mathrm{C}$ and transported to the University of Pretoria, Department of Veterinary of Tropical Diseases in a cold chain.

Routine tissue sample submission was carried out by the state veterinary officials between 2002 and 2013 from i) tuberculin skin test and gamma interferon test positive cattle from farms in KZN and ii) suspect lesions detected in cattle during routine slaughter at abattoirs. These were processed following standard operating procedures at the Onderstepoort Veterinary laboratories as outlined by Hlokwe (2014) [18]. In 2017, following slaughter of three test positive cows, one cow from each of the three dip tanks Nibela, Nkomo and Mpempe, appropriate samples were collected. Either the entire lymph node or approximately 5-10 g of tissue were collected from the head, thoracic and mediastinal lymph nodes and, where relevant, from bTB like lesions observed in other organs such as the lungs, liver, spleen, kidney and mammary glands.

\section{Wildlife tissue samples}

During the annual bTB management culling program in the HiP, tissue samples were collected from skin test or gamma interferon positive buffalo between 2002 and 
2017. In addition, samples were collected from other wild animals such as the lion, baboon and warthog in game reserves in $\mathrm{KZN}$ province that included $\mathrm{HiP}$, Munyawana and Mkhuze either during i) TB passive surveillance of all wild animals found dead or ii) culling of skin test or gamma interferon positive wildlife. The samples included submandibular, retropharyngeal, tracheobronchial, mediastinal, mesenteric lymph nodes as well as sections of tonsils, lungs and any tissues with granulomatous lesions.

All the tissue samples that were collected from cattle and wildlife were packaged into zip lock bags and transported frozen to the University of Pretoria-Department of Veterinary Tropical Diseases and Onderstepoort Veterinary Research BSL2+ laboratory for mycobacterial culture.

\section{Mycobacterium bovis culture and identification}

Raw milk was decontaminated using $1 \%$ cetylpyridinium chloride (CPC) and $2 \% \mathrm{NaCl}$ as previously described by Michel, 2015 [43]. The sediment from the centrifugation was inoculated onto Löwenstein-Jensen (LJ) media with pyruvate and an antibiotic cocktail consisting of polymyxin B $(200 \mathrm{IU} / \mathrm{ml})$, amphotericin B $(10 \mu \mathrm{g} / \mathrm{ml})$ carbenicillin $(100 \mu \mathrm{g} / \mathrm{ml})$ and trimethoprim $(10 \mu \mathrm{g} / \mathrm{ml})$ (NHLS, South Africa) and incubated at $37^{\circ} \mathrm{C}$ for 10 weeks. Decontamination of nasal swabs was done using the modified
Petroff method $(2 \% \mathrm{HCl})$, followed by centrifugation and the sediment treated with amphotericin B $(50 \mu \mathrm{g} / \mathrm{ml})$. The solution was inoculated onto LJ media with pyruvate and the above antibiotics and incubated at $37^{\circ} \mathrm{C}$ for 10 weeks with weekly monitoring.

The animal tissue samples were processed according to the method previously described by Alexander et al. (2002) [44]. Briefly, tissues samples were decontaminated using two methods with a final concentration of $2 \%$ $\mathrm{NaOH}$ and $1 \% \mathrm{HCl}$. These were inoculated on four slants of LJ media supplemented with pyruvate and incubated at $37^{\circ} \mathrm{C}$ for up to 10 weeks. The Ziehl-Neelsen (ZN) staining and culture characteristics (growth rate and colony morphology) were used to identify M. bovis isolates from tissue, nasal and milk cultures. DNA extraction was performed using the boiling method whereby the isolates were suspended in $100 \mu \mathrm{l}$ of sterile distilled water and heated to $95^{\circ} \mathrm{C}$ for 25 min using a heating block. Thereafter the DNA was stored at $-20^{\circ} \mathrm{C}$ and used in all the subsequent PCR based reactions [39]. $M$. bovis was confirmed using PCR that is performed using primers that target the Region of Difference (RD), RD4 and RD9 for deletion analysis as previously detailed by Warren, 2006 [45]. The distribution of the isolates according to animal species, location and sample type are as shown in Table 1.

Table 1 Animal species, their origins and numbers of $M$. bovis isolated

\begin{tabular}{|c|c|c|c|}
\hline Animal species & Location & Sample type & Number of $M$. bovis isolates \\
\hline \multirow[t]{15}{*}{ Cattle } & \multirow[t]{3}{*}{ Nibela dip tank } & organ tissues & 4 \\
\hline & & nasal swab & 3 \\
\hline & & Milk & 1 \\
\hline & \multirow[t]{3}{*}{ Mpempe dip tank } & organ tissues & 4 \\
\hline & & nasal swab & 1 \\
\hline & & Milk & 1 \\
\hline & \multirow[t]{2}{*}{ Masakeni dip tank } & organ tissues & 4 \\
\hline & & nasal swab & 1 \\
\hline & Nkomo dip tank & nasal swab & 1 \\
\hline & Nakunazaphe dip tank & organ tissues & 1 \\
\hline & Hlazana dip tank & organ tissues & 1 \\
\hline & Commercial farm 1 & organ tissues & 24 \\
\hline & Commercial farm 2 & organ tissues & 2 \\
\hline & Commercial farm 3 & organ tissues & 2 \\
\hline & Commercial farm 4 & organ tissues & 1 \\
\hline Buffalo & HiP game reserve & organ tissues & 41 \\
\hline Baboon & Mkhuze game reserve & organ tissues & 2 \\
\hline \multirow[t]{2}{*}{ Lion } & Munyawana game reserve & organ tissues & 2 \\
\hline & HiP game reserve & organ tissues & 2 \\
\hline Warthog & Mkhuze game reserve & organ tissues & 1 \\
\hline Grand Total & & & 99 \\
\hline
\end{tabular}




\section{Genotyping of Mycobacterium bovis isolates Spoligotyping}

Spoligotyping was applied to isolates that were confirmed as $M$. bovis using culture for further differentiation according to the standard protocol described by Kamerbeek 1997 [46]. Briefly, a PCR reaction was carried out to amplify the spacer sequence of the DR locus using primers DRa (biotinylated) and DRb. The spacer sequences were detected by hybridization of the biotin labelled amplified products using ECL against 43 spacer oligonucleotides covalently linked to a membrane. A commercially available kit was used, and the procedure was conducted according to the manufacturer's instructions (SPOLIGOTB, Mapmygenome, India). A specific pattern of hybridization signals was generated that represented the absence or presence of the spacer sequences presented in a binary code that was translated into a spoligotype octal code according to the established algorithm. The spoligotyping pattern were named following the nomenclature of the international $M$. bovis spoligotype database (www.Mbovis.org).

\section{Variable number of tandem repeats}

The M. bovis isolates were also genotyped by PCR amplification using a panel of 13 VNTR markers previously established for South African isolates by Hlokwe, van Helden and Michel, 2013 [39]. These include 4 ETRs loci (A, B, C, E), 3 MIRUs loci [16, 23, 26], QUBs loci $(11 \mathrm{a}, \mathrm{b}, 18,26)$ and $2 \mathrm{M}$. tubs $[12,21]$. The PCR reactions for each marker were carried out separately using specific primer sequences (Inqaba Biotechnical Industries, South Africa). The procedure was carried out as described by Le Flèche, 2002 [47]. In brief, a $20 \mu \mathrm{l}$ reaction was used for the PCR and it contained $2 \mu \mathrm{l}$ DNA template, $10 \mu$ l Qiagen master mix, $0.5 \mu \mathrm{l}$ of each of the two $10 \mu \mathrm{M}$ primers and $7 \mu \mathrm{l}$ of DNA free water. The PCR cycle of reactions were as follows: initial denaturation at $94{ }^{\circ} \mathrm{C}$ for $5 \mathrm{~min}$, followed by 40 cycles of initial denaturation at $94{ }^{\circ} \mathrm{C}$ for $1 \mathrm{~min}$, annealing at $62^{\circ} \mathrm{C}$ for $1 \mathrm{~min}$ and elongation at $72{ }^{\circ} \mathrm{C}$ for $1.5 \mathrm{~min}$ and the final elongation at $72{ }^{\circ} \mathrm{C}$ for $10 \mathrm{~min}$.

The PCR was carried out using the PCR thermocycler machine (2700, Applied Biosystems). The PCR products were separated electrophoretically using 3\% agarose gel at $85 \mathrm{~V}$ for $3 \mathrm{~h}$. The band sizes were estimated against a $100 \mathrm{bp}$ DNA ladder and converted into copy number that was saved as the digital VNTR profile in Excel [47]. The data was exported into Bionumerics software package version 7 (Applied Maths, Sint-Martens-Latem) as a character data for analysis.

The unweighted pair-group method using average linkages algorithm (UPGMA) was used to construct the relevant dendogram and the categorical coefficient was used to calculate the similarity of the Multi locus VNTR analysis (MLVA) profiles. In this study, a cluster was defined as a group of isolates with $100 \%$ genetic similarity. Additional information on the year of sample collection, location of sample collection (dip tank/game reserve/ farm), animal species and type of sample collected was used to define the links between specific clusters. The MIRU-VNTR profile was analysed together with its corresponding spoligotype from this study and combined with results from previous studies in the province [18].

\section{Abbreviations \\ bTB: Bovine tuberculosis; DRs: Direct repeats; HiP: Hluhluwe iMfolozi Park; KZN: KwaZulu-Natal; LJ: Löwenstein-Jensen; MIRU-VNTR: Mycobacteria interspersed repetitive unit-variable number of tandem repeats; MLVA: Multi locus VNTR analysis; PCR: Polymerase Chain Reaction; RD: Region of \\ Differences; UPGMA: Unweighted pair-group method using average linkages algorithm; ZN: Ziehl Neelsen}

\section{Acknowledgements}

We thank the Institute of Tropical Medicine (ITM-Belgium) for funding the research study. The authors appreciate the co-operation of all animal health technicians from the Big 5 False Bay Municipality State Veterinary office: Warren McCall, Alicia McCall, Simon Mkwamubi, Godfrey Makhubu, Ipeleng

Tshetlhanyane for organizing and taking part in the field work for collection of samples from cattle at the dip tanks. We are grateful to the farmers and cattle keepers for their co-operation during the study and to the Ezemvelo kwa-Zulu Natal Wildlife team for providing the wildlife samples. We are indebted to Dr. Ayesha Hassim for the analysis of the data and construction of the dendogram. Last but not least, we acknowledge Kgwaredi (KG) Ledwaba and Pamela Wambulawaye for technical support.

\section{Authors' contributions}

ALM, EMCE, PRS contributed to the conceptualization of the study, methodology, interpretation of the data and the writing of the draft manuscript. ALM, PRS, TMH were involved in the field investigation, sample collection and laboratory work. ALM acquired the funds that were used in the study. All authors read and approved the final manuscript.

\section{Funding}

This was funded by the National Research Foundation (NRF) Grant, South Africa and the Institute of Tropical Medicine, Belgium under the FA4 grant agreement with the Department of Tropical Diseases, University of Pretoria, South Africa.

\section{Availability of data and materials}

The datasets used and analysed during the current study are available from the corresponding author on reasonable request.

\section{Ethics approval and consent to participate}

Participation in the study by the farmers was voluntary and collection of samples was done after explaining the project fully to the farmers and obtaining verbal consent. The animals that were slaughtered were purchased from the farmers at the agreed price and a consent form was signed by the farmer. Ethics permission to collect animal samples was obtained from the University of Pretoria, Animal Ethics Committee (ref: V078-16, VO50-16,V136-16) and the Department of Agriculture Forestry and Fisheries (DAFF) under the Section 20 (ref: 12/11/1/1/6/1). Animal samples were also collected and submitted by the State Veterinary Officers as mandated by the National Department of Agriculture, land Reforms and rural Development for TB diagnostic testing of animals according to the animal disease legislation act 35 of 1984 for bovine tuberculosis control in South Africa.

Consent for publication

Not applicable.

Competing interests

The authors declare that they have no competing interests. 


\section{Author details}

'Department of Veterinary Tropical Diseases, Bovine Brucellosis and Tuberculosis Research Programme, Faculty of Veterinary Science, University of Pretoria, Pretoria, Republic of South Africa. ${ }^{2}$ Department of Animal Sciences, Faculty of Natural Resources Management and Agriculture, Midlands State University, Gweru, Zimbabwe. ${ }^{3}$ Diagnostic Services Programme, ARC-Onderstepoort Veterinary Research, Pretoria, Republic of South Africa. ${ }^{4}$ Department of Animal Production Studies, Faculty of Veterinary Science, University of Pretoria, Pretoria, Republic of South Africa. ${ }^{5}$ CIRAD, UMR Animal, Santé, Territoires, Risque et Ecosystèmes (ASTRE), Montpellier, France. ${ }^{6}$ ASTRE, Univ Montpellier, CIRAD, INRA, Montpellier, France. ${ }^{7}$ Research Associate at the National Zoological Gardens of South Africa, Pretoria, South Africa.

\section{Received: 8 October 2019 Accepted: 24 February 2020} Published online: 04 March 2020

\section{References}

1. Michel AL, Müller B, van Helden PD. Mycobacterium bovis at the animalhuman interface: a problem, or not? Vet Microbiol. 2010;140(3-4):371-81.

2. Caron A, de Garine-Wichatitsky M And RF. Bovine tuberculosis: a doubleedged issue at the human/livestock/wildlife interface in Africa. Empres -animal health 2014;44(2):10-13.

3. Machado A, Santos N, Zinsstag J, Correia-neves M. Prevalence of Bovine Tuberculosis and Risk Factor Assessment in Cattle in Rural Livestock Areas of Govuro District in the Southeast of Mozambique. PLoS One. 2014;9(3): e91527.

4. Munyeme M, Muma JB, Samui KL, Skjerve E, Nambota AM, Phiri IGK, et al. Prevalence of bovine tuberculosis and animal level risk factors for indigenous cattle under different grazing strategies in the livestock/wildlife interface areas of Zambia. Trop Anim Health Prod. 2009;41(3):345-52.

5. Thoen CO, Lobue PA, Enarson DA, Kaneene JB, de Kantor IN. Tuberculosis : a re - emerging disease in animals and humans. Vet Ital. 2009;45(1):135-81.

6. Katale BZ, Mbugi EV, Siame KK, Keyyu JD, Kendall S, Kazwala RR, et al. Isolation and potential for transmission of Mycobacterium bovis at human livestock - wildlife Interface of the Serengeti ecosystem, Northern Tanzania. Transboundary Emerg Dis. 2017;64(3):815-25.

7. Etter E, Donado P, Jori F. Risk analysis and bovine tuberculosis, a reemerging zoonosis. Ann N Y Acad Sci. 2006;73:61-73.

8. Jori F, Etter E. Transmission of foot and mouth disease at the wildlife / livestock interface of the Kruger National Park, South Africa : Can the risk be mitigated ? Prev Vet Med. 2016;126(2016):19-29. Available from:. https:// doi.org/10.1016/j.prevetmed.2016.01.016.

9. de Garine-Wichatitsky M, Caron A, Kock R, Tschopp R, Munyeme M, Hofmeyer $M$, et al. A review of bovine tuberculosis at the wildlife-livestockhuman interface in sub-Saharan Africa. Epidemiol Infect. 2013;141(07):134256 [cited 2018 Apr 11] Available from:http://www.journals.cambridge.org/ abstract_S0950268813000708

10. Musoke J, Hlokwe T, Marcotty T, Du Plessis BJA, Michel AL. Spillover of mycobacterium bovis from wildlife to livestock, South Africa. Emerg Infect Dis. 2015;21(3):448-51.

11. Hang'ombe MB, Munyeme M, Nakajima C, Fukushima Y, Suzuki H, Matandiko W, et al. Mycobacterium bovis infection at the interface between domestic and wild animals in Zambia. BMC Vet Res. 2012;8:221.

12. Palmer MV. Mycobacterium bovis: Characteristics of Wildlife Reservoir Hosts. Transboundary Emerg Dis. 2013;60:1-13 [cited 2018 Nov 30] Available from: http://www.ncbi.nlm.nih.gov/pubmed/24171844.

13. Fink M, Schleicher C, Gonano M, Prodinger WM, Pacciarini M, Glawischnig W, et al. Red Deer as maintenance host for bovine tuberculosis. Alpine Region Emerging Infectious Diseases. 2015;21(3):3-6.

14. Zanella G, Duvauchelle A, Hars J, Moutou F, Boschiroli ML, Durand B. Papers $\&$ Articles Patterns of lesions of bovine tuberculosis in wild red deer and wild boar. Vet Rec. 2008;163(2008):43.

15. Santos N, Almeida V, Gortázar C, Neves MC. Patterns of Mycobacterium tuberculosis - complex excretion and characterization of super - shedders in naturally - infected wild boar and red deer. Vet Res. 2015;46(129):1-10.

16. Fitzgerald SD, Kaneene JB. Wildlife Reservoirs of Bovine Tuberculosis Worldwide: Hosts, Pathology, Surveillance, and Control. Vet Pathol. 2013; 50(3):488-99 [cited 2018 Jul 20]Available from: http://journals.sagepub.com/ doi/pdf/10.1177/0300985812467472.
17. Miller M. Tuberculosis in South African wildlife: Why is it important? [Internet]. 2015 [cited 2019 Feb 18]. Available from: http://www.sun.ac.za/ english/Inaugurallectures/Inaugural lectures/InauguralLectureProfMiller.pdf.

18. Hlokwe TM, van Helden P, Michel AL. Evidence of increasing intra and interspecies transmission of Mycobacterium bovis in South Africa: are we losing the battle? Prev Vet Med. 2014;115(1-2):10-7.

19. Renwick AR, White PCL, Bengis RG. Bovine tuberculosis in southern African wildlife: a multi-species host-pathogen system. Epidemiol Infect. 2007;135(4): 529-40 Available from: http://www.pubmedcentral.nih.gov/articlerender. fcgi?artid=2870607\&tool=pmcentrez\&rendertype=abstract.

20. Ayele WY, Neill SD, Zinsstag J, Weiss MG, Pavlik I. Bovine tuberculosis: an old disease but a new threat to Africa. Int J Tuberc Lung Dis. 2004;8(8):924-37.

21. Michel AL, Hlokwe TM, Coetzee ML, Maré L, Connoway L, Rutten VPMG, et al. High Mycobacterium bovis genetic diversity in a low prevalence setting. Vet Microbiol. 2008;126(1-3):151-9.

22. Michel AL, Coetzee ML, Keet DF, Maré L, Warren R, Cooper D, et al. Molecular epidemiology of Mycobacterium bovis isolates from free-ranging wildlife in south African game reserves. Vet Microbiol. 2009;133(4):335-43.

23. Thoen C, LoBue P, De Kantor I. The importance of Mycobacterium bovis as a zoonosis. Vet Microbiol. 2006;112(2-4 SPEC. ISS):339-45.

24. Cleaveland S, Shaw DJ, Mfinanga SG, Shirima G, Kazwala RR, Eblate E, et al. Mycobacterium bovis in rural Tanzania : risk factors for infection in human and cattle populations. Tuberculosis. 2007;87:30-43.

25. Sichewo PR, Michel AL, Musoke J, Etter EMC. Risk factors for zoonotic tuberculosis at the wildlife - livestock - human Interface in South Africa. Pathogens. 2019;8(101):1-14

26. Mwakapuja RS, Makondo ZE, Malakalinga J, Moser I, Kazwala RR, Tanner M. Molecular characterization of Mycobacterium bovis isolates from pastoral livestock at Mikumi-Selous ecosystem in the eastern Tanzania. Tuberculosis. 2013;93(6):668-74. Available from:. https://doi.org/10.1016/j.tube.2013.08.002.

27. Supply P, Allix C, Lesjean S, Cardoso-oelemann M, Ru S, Willery E, et al. Proposal for standardization of optimized mycobacterial interspersed repetitive unit - variable-number tandem repeat typing of Mycobacterium tuberculosis †. J Clin Microbiol. 2006:44(12):4498-510.

28. Gori A, Bandera A, Marchetti G, Esposti AD, Catozzi L, Nardi GP, et al, Spoligotyping and Mycobacterium tuberculosis. Emerg Infect Dis. 2005;11(8): 1242-8. Available from: http://www.ncbi.nlm.nih.gov/pubmed/16102314

29. Galagan JE. Genomic insights into tuberculosis. Nat Rev Genet. 2014;15(5): 307-20 [cited 2018 May 26]Available from: https://www.nature.com/articles/ nrg3664.pdf.

30. Cosivi O, Grange JM, Daborn CJ, Raviglione MC, Fujikura T, Cousins D, et al. Zoonotic tuberculosis due to Mycobacterium bovis in developing countries. Emerg Infect Dis. 1998;4(1):59-70.

31. Hokwe TM, Jenkins AO, Streicher EM, Venter EH, Cooper D, Godfroid J, et al. Molecular characterisation of Mycobacterium bovis isolated from African buffaloes (Syncerus caffer) in Hluhluwe-iMfolozi park in KwaZulu-Natal, South Africa. Onderstepoort J Vet Res. 2011;78(1):232-7 Available from: http://www.ncbi.nlm.nih.gov/pubmed/23327208.

32. Sichewo PR, Marcel E, Etter C, Michel AL. Prevalence of Mycobacterium bovis infection in traditionally managed cattle at the wildlife-livestock interface in South Africa in the absence of control measures. Vet Commun. 2019;43(3):155-64.

33. Machado A, Rito T, Ghebremichael S, Muhate N, Maxhuza G, Macuamule C, et al. Genetic diversity and potential routes of transmission of Mycobacterium bovis in Mozambique. 2018 [cited 2018 Oct 14]; Available from: https://doi.org/10.1371/journal.pntd.0006147.

34. Sichewo PR, Etter EMC, Michel AL. Wildlife-cattle interactions emerge as drivers of bovine tuberculosis in traditionally farmed cattle. Prev Vet Med. 2020;174(April 2019):104847 Available from: https://doi.org/10.1016/j. prevetmed.2019.104847.

35. Shirima GM, Kazwala RR, Kambarage DM. Prevalence of bovine tuberculosis in cattle in different farming systems in the eastern zone of Tanzania. Prev Vet Med. 2003:57(3):167-72 [cited 2019 Feb 14] Available from: http://www. ncbi.nlm.nih.gov/pubmed/12581599.

36. Oloya J, Muma JB, Opuda-asibo J, Djønne B. Risk factors for herd-level bovine-tuberculosis seropositivity in transhumant cattle in Uganda. Prev Vet Med. 2007;80(2007):318-29.

37. Tschopp R, Schelling E, Hattendorf J, Aseffa A, Zinsstag J. Risk factors of bovine tuberculosis in cattle in rural livestock production systems of Ethiopia. Prev Vet Med. 2009;89(2009):205-11.

38. Furphy C, Costello E, Murphy D, Corner LAL, Gormley E. DNA typing of Mycobacterium bovis isolates from badgers ( Meles meles) culled from 
areas in Ireland with different levels of tuberculosis prevalence DNA typing of Mycobacterium bovis isolates from badgers ( Meles meles ) culled from areas in Ireland with. Vet Med Int. 2012;2012(April):1-6.

39. Hlokwe TM, van Helden P, Michel A. Evaluation of the Discriminatory Power of Variable Number of Tandem Repeat Typing of Mycobacterium bovis Isolates from Southern Africa. Transboundary Emerg Dis. 2013;60:111-20 [cited 2018 Jun 2]Available from: http://www.ncbi.nlm.nih.gov/pubmed/24171856.

40. Hauer A, De Cruz K, Cochard T, Godreuil S, Karoui C, Henault S. Genetic Evolution of Mycobacterium bovis Causing Tuberculosis in Livestock and Wildlife in France since 1978 Genetic evolution of Mycobacterium bovis causing tuberculosis in livestock and wildlife in France since 1978. PLoS One. 2015, 10(2):e0117103.

41. Haddad N, Ostyn A, Karoui C, Masselot M, Thorel MF, Hughes SL, et al. Spoligotype diversity of Mycobacterium bovis strains isolated in France from 1979 to 2000. J Cin Microbiol. 2001:39(10):3623-32.

42. Michel AL, Bengis RG, Keet DF, Hofmeyr M, De Klerk LM, Cross PC, et al. Wildlife tuberculosis in South African conservation areas: Implications and challenges. Vet Microbiol. 2006;112(2-4 SPEC. ISS):91-100.

43. Michel AL, Geoghegan C, Hlokwe T, Raseleka K, Getz WM, Marcotty T. Longevity of Mycobacterium bovis in raw and traditional souring milk as a function of storage temperature and dose. PLoS ONE. 2015;10(6):1-12. Available from: https://doi.org/10.1371/journal.pone.0129926.

44. Alexander KA, Pleydell E, Williams MC, Lane EP, Nyange JFC, Michel AL. Mycobacterium tuberculosis : an emerging disease of free-ranging wildlife. Emerg Infect Dis. 2002;8(6):598-601.

45. Warren RM, Gey Van Pittius NC, Barnard M, Hesseling A, Engelke E, De Kock $M$, et al. Differentiation of Mycobacterium tuberculosis complex by PCR amplification of genomic regions of difference. Int J Tuberc Lung Dis. 2006;10(7):818-22.

46. Kamerbeek J, Schouls LEO, Kolk A, van Agterveld M, van Soolingen D, Kuijper $\mathrm{S}$, et al. Simultaneous detection and strain differentiation of Mycobacterium tuberculosis for diagnosis and epidemiology. J Cin Microbiol. 1997:35(4):907-14.

47. Le Flèche P, Fabre M, Denoeud F, Koeck J-L, Vergnaud G. High resolution, on-line identification of strains from the Mycobacterium tuberculosis complex based on tandem repeat typing. BMC Microbiology. 2002;2:37 [cited 2018 Jun 2] Available from: http://www.ncbi.nlm.nih.gov/ pubmed/12456266.

\section{Publisher's Note}

Springer Nature remains neutral with regard to jurisdictional claims in published maps and institutional affiliations.

Ready to submit your research? Choose BMC and benefit from:

- fast, convenient online submission

- thorough peer review by experienced researchers in your field

- rapid publication on acceptance

- support for research data, including large and complex data types

- gold Open Access which fosters wider collaboration and increased citations

- maximum visibility for your research: over $100 \mathrm{M}$ website views per year

At $\mathrm{BMC}$, research is always in progress.

Learn more biomedcentral.com/submissions 